\title{
CALOPLACA MONACENSIS (TELOSCHISTACEAE, LICHENIZED ASCOMYCOTA), A SPECIES NEW FOR POLAND
}

\author{
DARIUSZ KUBIAK ${ }^{1} \&$ KARINA WILK
}

\begin{abstract}
Caloplaca monacensis (Leder.) Lettau is reported as a new lichen species for Poland. It is an old species of the Caloplaca cerina group, forgotten for decades and resurrected most recently. This epiphytic species is characteristic for open habitats such as roadside trees. The new records are from northern (Pojezierze Olsztyńskie lakeland) and southern (Carpathians) Poland. Brief taxonomic remarks and data on habitat preferences and the known distribution are provided.
\end{abstract}

Key words: biodiversity, distribution, endangered species, epiphytic species, lichenized fungi, Ulmus

Dariusz Kubiak, Department of Mycology, University of Warmia and Mazury in Olsztyn, Oczapowskiego 1A, 10-719 Olsztyn, Poland; e-mail: darkub@uwm.edu.pl

Karina Wilk, Laboratory of Lichenology, W. Szafer Institute of Botany, Polish Academy of Sciences, Lubicz 46, 31-512 Kraków, Poland; e-mail: k.wilk@botany.pl

\section{INTRODUCTION}

At present the genus Caloplaca s.l. is represented by 81 species in Poland (Wilk 2012, 2015; Szczepańska et al. 2013; Frolov et al. 2016). Most recently, two new species were described (C. micromontana Frolov, Wilk \& Vondrák, C. microstepposa Frolov, Nadyeina, Khodos. \& Vondrák; Frolov et al. 2016), based in part on material from Poland published previously under the name C. atroalba (Tuck.) Zahlbr. (Wilk 2011, 2012). Various ecological groups of the genus are not evenly investigated in Poland. Saxicolous representatives of the genus occurring on calcium-rich substrate were the subject of detailed taxonomic studies (Wilk 2012). Saxicolous taxa occurring on acidic rock have not been covered by a detailed taxonomic survey so far; nor have corticolous, terricolous and muscicolous species. Around 13 corticolous species have been reported from Poland (Fałtynowicz 2003), most of them are rare species included in the Red List of lichens in high risk categories, e.g., Athallia cerinella (Nyl.) Arup, Frödén \& Søchting [= C. cerinella (Nyl.) Flagey], Calogaya lobulata (Flörke) Arup, Frödén

\footnotetext{
1 Corresponding author
}

\& Søchting $[=C$. lobulata (Flörke) Hellb.], Caloplaca lucifuga G. Thor and Cerothallia luteoalba (Turner) Arup, Frödén \& Søchting, (Turner) Th. Fr. [= Caloplaca luteoalba (Turner) Th. Fr.]; (Cieśliński et al. 2006; Kubiak \& Zalewska 2009).

This paper reporting a newly recorded corticolous species $C$. monacensis (Leder.) Lettau is part of a project evaluating epiphytic lichen diversity in one of the last Ulmus avenues in the Pojezierze Olsztyńskie lakeland, conducted by the first author. Tree avenues play an important role in the conservation of rare and endangered lichen species. The mass extinction of Ulmus brought on by an epidemic of Dutch elm disease, combined with the cessation of new elm planting (NapierałaFilipiak et al. 2014), created a threat to many lichen species preferring Ulmus bark (Watson et al. 1988). In view of the valuable biocenotic role elm plays, this tree should be used more frequently in all kinds of plantings.

During a field survey in the Pojezierze Olsztynskie lakeland in 2015, C. monacensis was found on the bark of Ulmus laevis Pall. Later, an examination of herbarium material yielded additional specimens of $C$. monacensis originating from three 

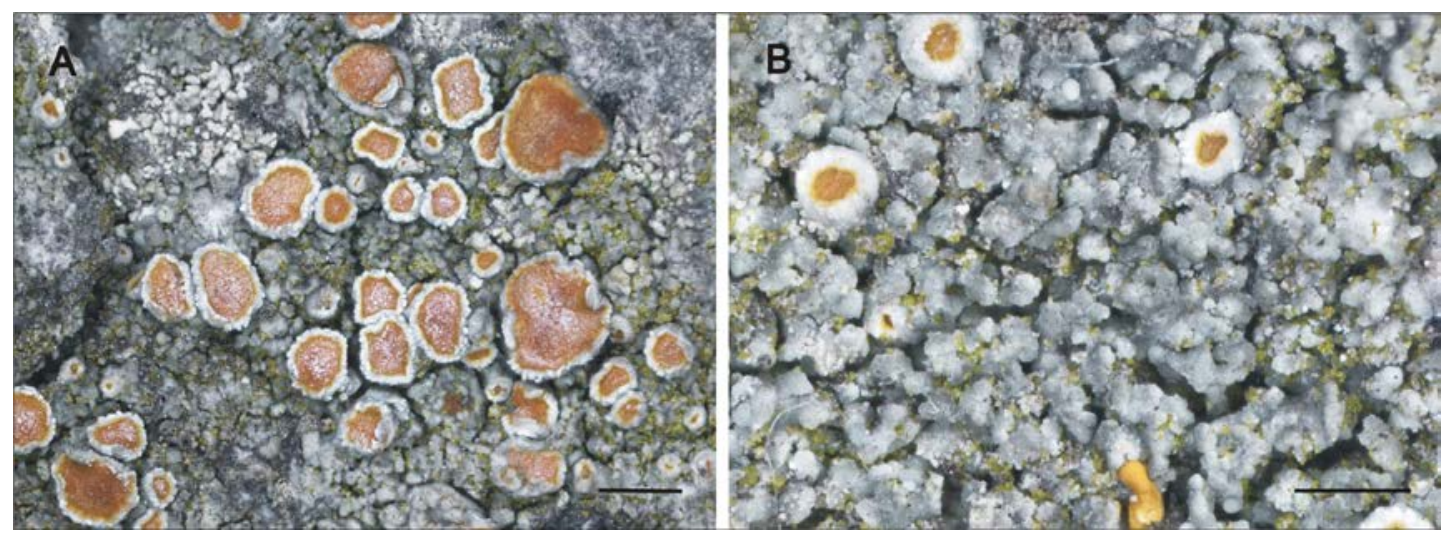

Fig. 1. Caloplaca monacensis (Leder.) Lettau (D. Kubiak, OLTC L-3574): A - habit, B - details of thallus with vegetative propagules. Scale bars: $\mathrm{A}=1 \mathrm{~mm} ; \mathrm{B}=0.5 \mathrm{~mm}$.

collecting sites in the Polish Western Carpathians and from the bark of Fraxinus excelsior L. and wood. Taxonomically, C. monacensis belongs to the well-delimited C. cerina group (Šoun et al. 2011), whose members produce typical lecanorine apothecia. Four Caloplaca species of that group are known from Poland: C. cerina (Hedw.) Th. Fr. s.l., C. chlorina (Flot.) Sandst., C. isidiigera Vězda and $C$. stillicidiorum (Vahl.) Lynge s.l. Only one of them, C. cerina, is an epiphytic species. Here we provide information on the most characteristic features of C. monacensis, its habitat preferences and known geographical range, and discuss its taxonomic affinities.

\section{MATERIAL AND METHODS}

The study is based on material from OLTC and KRAM. Morphology and anatomy were observed using standard light microscopy techniques. Anatomical measurements were made from hand-cut sections and squash preparations mounted in water. The granulation of anatomical structures was observed in polarized light. The solubility of granules/crystals was tested with $25 \% \mathrm{KOH}(\mathrm{K})$ and $65 \%$ nitric acid $(\mathrm{N})$. The same chemicals were used for color reactions.

\section{THE SPECIES}

Caloplaca monacensis (Leder.) Lettau Figs 1-3 Hedwigia 52: 240. 1912. 三 Pyrenodesmia monacensis Leder., Bericht. Bayr. Botan. Gesellsch. 4: 26. 1896.
This species is a member of the C. cerina group (Šoun et al. 2011). It was poorly known and often misidentified as C. cerina (Hedw.) Th. Fr. s.l. Recently the species was resurrected and circumscribed by Šoun et al. (2011), and is easier to recognize at present.

The studied specimens of $C$. monacensis have a distinctive grey thallus consisting of coarse granules, small squamules and isidia, and truly lecanorine apothecia. The apothecia are abundant and large, up to $1.5 \mathrm{~mm}$ in diameter; the apothecial disc is orange, often pruinose. The apothecial cortex is paraplectenchymatous, very thick, $c a 170 \mu \mathrm{m}$ wide in the lower part of the margin, with some crystals in the upper part (pol+ white, insoluble in $\mathrm{K}$, soluble in $\mathrm{N}$ ). The ascospores are polarilocular, ellipsoid, with dimensions $11.5-15.0 \times 6.0-8.0 \mu \mathrm{m}$, and the septum is $4.0-6.0 \mu \mathrm{m}$ wide.

Among the species of Caloplaca s.l. occurring in Poland, C. monacensis may be confused with C. cerina s.l., but the latter species differs in having a smooth, cracked areolate thallus without any vegetative propagules, and ascospores with a distinctly thicker septum $[(5-) 6.7 \pm 1.2(-10) \mu \mathrm{m}$; Šoun et al. 2011]. Another similar species, C. chlorina, differs from $C$. monacensis in having a distinctly areolate thallus (granular in C. monacensis, rarely with distinct areoles), soredia and blastidia, and it occurs mainly on rock. The poorly known species $C$. virescens $(\mathrm{Sm}$.) Coppins also seems to resemble C. monacensis but it differs in having 
a well developed, areolate, rarely fertile thallus with a thick layer of small granules on its surface. The North American species C. ulmorum (Fink) Fink is closely related to $C$. monacensis. It differs from $C$. monacensis in having a more developed areolate thallus with marginal and regular granules (Šoun et al. 2011).

Caloplaca monacensis is characteristic for solitary trees such as roadside trees or single trees in pastures or other types of agricultural landscape, as well as for open deciduous or mixed forests. It grows on bark of a variety of broadleaved trees (e.g., Acer, Fagus, Fraxinus, Juglans, Malus, Ostrya, Pistacia, Populus, Pyrus, Quercus, Salix, Tilia, Ulmus; Šoun et al. 2011; Muchnik et al. 2014). The species has been collected rarely from bark of Larix and rotten wood (Šoun et al. 2011; Hauck et al. 2013), and exceptionally was found growing on limestone (Vondrák et al. 2009). At the collecting site in the Pojezierze Olsztyńskie lakeland, C. monacensis occurs on Ulmus laevis $(97 \mathrm{~cm} \mathrm{DBH})$ in an old tree avenue composed of Fraxinus and Ulmus. It grew on the southern side of a tree trunk at 150-170 cm height. The species was accompanied by the following lichens: $B a$ cidia rubella (Hoffm.) A. Massal., Buellia punctata (Hoffm.) A. Massal., Candelariella xanthostigma (Pers. ex Ach.) Lettau, Lecanora expallens Ach., L. persimilis (Th. Fr.) Arnold, Phaeophyscia orbicularis (Neck.) Moberg, Phlyctis argena (Ach.) Flot., Physcia adscendens (Fr.) H. Olivier,

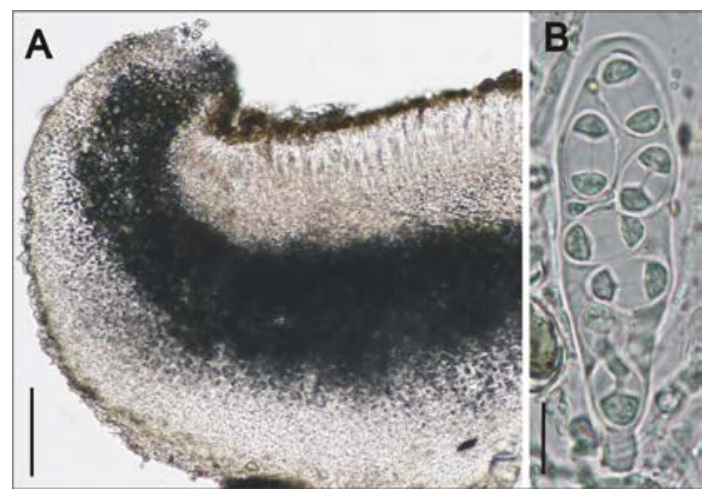

Fig. 2. Caloplaca monacensis (Leder.) Lettau (J. Nowak, KRAM L-68117): A - vertical section of apothecium, B ascus with spores. Scale bars $A=100 \mu \mathrm{m} ; \mathrm{B}=10 \mu \mathrm{m}$.

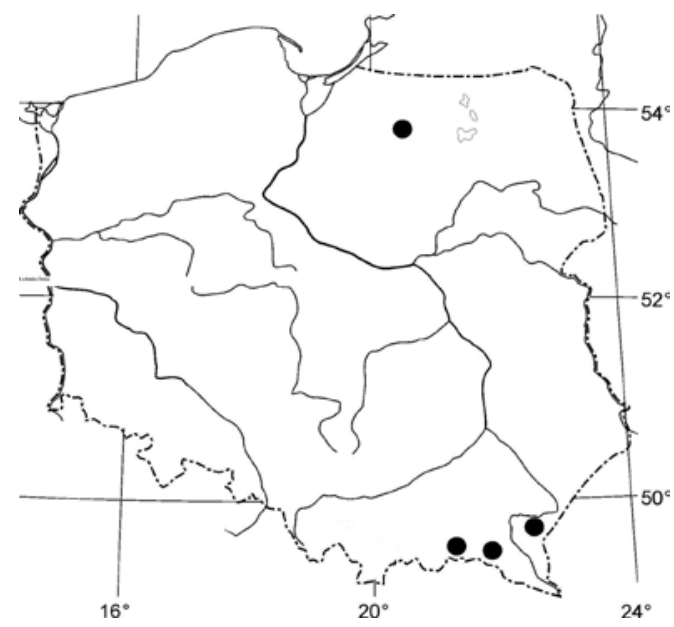

Fig. 3. Known distribution of Caloplaca monacensis (Leder.) Lettau in Poland.

P. tenella (Scop.) DC., Physconia grisea (Lam.) Poelt, Pseudoschismatomma rufescens (Pers.) Ertz $\&$ Tehler and Xanthoria parietina (L.) Th. Fr. At the sites in the Western Carpathians (Pogórze Przemyskie foothills and Beskid Niski Mts.) the species occurred in sunny places, on roadside Fraxinus excelsior trees and on a wood shingle of a house roof.

Caloplaca monacensis is known throughout temperate and Mediterranean Europe, and Asia (see Šoun et al. 2011). The species is perhaps widespread but still under-recorded. Most recently it was reported from Romania (Malíček et al. 2015), central European Russia (Muchnik et al. 2014), Kazakhstan (Hauck et al. 2013) and Iran (Kazemi \& Safavi 2014).

Specimens examined. POLAND. Pojezierze OLSZTYŃSKIE LAKELAND. Bartąg village, $53^{\circ} 42^{\prime} 57^{\prime \prime} \mathrm{N}$, $20^{\circ} 28^{\prime} 29^{\prime \prime}$, ATPOL-Be52, on Ulmus laevis, 9 May 2015, D. Kubiak (OLTC L-3574). Western CarPATHIANS. BESKID NISKI MTs: Jasło County, Czarne near Nieznajowa village, alt. $c a .470 \mathrm{~m}$, on wood shingle of house roof, 4 Oct. 1979, J. Nowak (KRAM L-32489); Jaśliska village, on Fraxinus excelsior, 2 Sept. 1977, $J$. Nowak (KRAM L-68117) [the specimen will be part of the next fascicle (XI) of Lichenes Poloniae Meridionalis Exsiccati]. - PogóRze Przemyskie FoOthills. Łodzinka Dolna village, near church by the road to Bircza, on Fraxinus excelsior, 29 June 1986, J. Kiszka \& J. Piórecki (KRAM L-55816). 
Acknowledgements. We thank Ulf Arup (Lund, Sweden) for confirmation of the C. monacensis identification, and the anonymous reviewer for helpful remarks and suggestions on the manuscript. This work was financially supported by statutory funds of the Department of Biology and Biotechnology, University of Warmia and Mazury in Olsztyn (DK) and of the W. Szafer Institute of Botany, Polish Academy of Sciences (KW).

\section{REFERENCES}

Cieśliński S., Czyżewska K. \& Fabiszewski J. 2006. Red list of the lichens in Poland. In: Z. MireK, K. ZARZYCKI, W. Wojewoda \& Z. SzeląG (eds), Red list of plants and fungi in Poland, pp. 71-89. W. Szafer Institute of Botany, Polish Academy of Sciences, Kraków.

Faltynowicz W. 2003. The lichens, lichenicolous and allied fungi of Poland. An annotated checklist. W. Szafer Institute of Botany, Polish Academy of Sciences, Kraków.

Frolov I., Vondrák J., Fernández-Mendoza F., Wilk K., Khodosovtsev A. \& Halici M. G. 2016. Three new, seemingly-cryptic species in the lichen genus Caloplaca (Teloschistaceae) distinguished in two-phase phenotype evaluation. Ann. Bot. Fenn. 53: 243-262.

Hauck M., Tønsberg T., Mayrhofer H. \& Breuss O. 2013. Lichen-forming and lichenicolous fungi new to Kazakhstan. Herzogia 26: 103-116.

Kazemi S. S. \& Safavi S. R. 2014. Three new records of Lichen species from Iran. Iran. J. Bot. 20(2): 236-239.

Kubiak D. \& ZalewsKa A. 2009. Notes on Caloplaca lucifuga (Teloschistales, Ascomycota) in Poland. Acta Mycol. 44(2): 239-248.
MalíčeK J., Bouda F., LišKa J., Palice Z. \& Peksa O. 2015. Contribution to the lichen biota of the Romanian Carpathians. Herzogia 28: 713-735.

Muchnik E., Wilk K., Vondrák J. \& Frolov I. 2014. Contribution to the knowledge of the genus Caloplaca in central European Russia. Polish Bot. J. 59(2): 263-270.

Napierala-FilipiaK A., Filipiak M. \& JaworeK J. 2014. Distribution of elms (Ulmus spp.) in Polish forests according to the forestry inventory data. Sylwan 158(11): 811-820 (in Polish with English summary).

Šoun J., Vondrák J., Søchting U., Hrouzek P., KhodoSOVTSEV A. \& ARup U. 2011. Taxonomy and phylogeny of the Caloplaca cerina group in Europe. Lichenologist 43(2): 113-135.

SzczepańsKa K., KossowsKa M. \& Wilk K. 2013. Caloplaca subpallida (Teloschistaceae), a lichen species new to Poland: distribution, ecology and taxonomic affinities. Acta Soc. Bot. Poloniae 82(1): 85-89.

Vondrák J., Šoun J., Redchenko O., LöKös L. \& KhodoSovtsev A. 2009. Populations of two Caloplaca species with peculiar ecology observed in the Bükk Mts, Hungary. Bryonora 44: 8-12.

Watson M. F., Hawksworth D. L. \& Rose F.1988. Lichens on elms in the British Isles and the effect of dutch elm disease on their status. Lichenologist 20(4): 327-352.

WILK K. 2011. New or noteworthy records of Caloplaca (Teloschistaceae) from Poland. Mycotaxon 115: 83-98.

WILK K. 2012. Calcicolous species of the genus Caloplaca in the Polish Western Carpathians. Polish Bot. Stud. 29: 1-91.

WILK K. 2015. Four species of Caloplaca s.1. (lichenized Ascomycota, Teloschistaceae) new for Poland. Polish Bot. J. 60(2): 197-201. 